Arhe XVIII, 36/2021

UDK 179

$17: 316.485 .26$

DOI https://doi.org/10.19090/arhe.2021.36.323-352

Originalni naučni rad

Original Scientific Article

IVICA KELAM ${ }^{1}$

J. J. Strossmayer University of Osijek, Faculty of Education/Faculty of

Kinesiology, Croatia

TOMISLAV NEDIĆ ${ }^{2}$

J. J. Strossmayer University of Osijek, Academy of Art and Culture, Croatia

\title{
THE LEGAL AND ETHICAL ASPECTS OF THE USE OF LETHAL AUTONOMOUS WEAPON SYSTEMS IN WARFARE
}

\begin{abstract}
The development of new technologies has always found its first application in warfare, from the invention of the bow and arrow, through the discovery of gunpowder, to the use of unmanned aerial vehicles in the "War on Terror." The "successful" use of drones in the targeted killings of "terrorists" gave additional impetus to the development of new types of autonomous weapons that completely replace soldiers of blood and flesh on the battlefield. Currently, there is significant controversy over fully autonomous weapons that are fully autonomous in carrying out military operations. They can autonomously decide on the use of deadly force against "enemy" human beings. This kind of autonomy causes numerous controversies, not only legal but also ethical. Moreover, it calls into question the very essence of man, i.e., whether the "killer robot" is the next evolutionary stage in the development of the human species or a technological return to barbarism. This paper will analyze some of the above legal and ethical dilemmas that await us in the near future.
\end{abstract}

Keywords: autonomy, law, ethics, human dignity, killer robot

\footnotetext{
${ }^{1}$ Author's e-mail address: kelamivica@gmail.com

${ }^{2}$ Author's e-mail address: nedict@gmail.com
} 


\section{INTRODUCTION}

Simultaneous fascination and terrorization of people with the potential of robotics and artificial intelligence to fundamentally change or potentially end human life on this planet is best symbolized in the Terminator film series. An artificial intelligence called Skynet rebels against its human creators and goes to war to exterminate humanity. Although the Terminator screenplay seems to be pure fiction and will never materialize, the rapid development of robotics and the intensive development of artificial intelligence has led to a heated debate among scientists about the possible consequences of developing new weapons for autonomous military action. In the current discussion on autonomous weapon systems, a fundamental question arises, whether these systems represent only the latest iteration in the evolution of weapons dating back to the dawn of human existence or whether it is an unprecedented change from the weapons used so far. The discussion focuses on two fundamental issues, issues of law and ethics. In this sense, the question arises, are traditional rules on armed conflict, as described in detail in the Hague and Geneva Conventions, sufficient to protect human rights in the robotic age of warfare? Can these legal principles also provide a satisfactory legal framework for using autonomous weapons systems in future warfare? Another fundamental issue throughout the debate on autonomous weapon systems concerns the ethics of their use in armed conflicts in the near future. In particular, is it at all ethical to leave such a crucial and life decision to take someone else's human life to the machine? Since, in our opinion, the future use of lethal autonomous weapons systems would be profoundly unethical and illegal. This paper will analyze the legal and ethical aspects of the potential use of lethal autonomous weapons systems (LAWS).

\section{DEFINITION OF KILLER ROBOTS OR LETHAL AUTONOMOUS WEAPON SYSTEMS}

According to some interpretations, the development of a definition of a fully lethal autonomous weapons system (LAWS) is 
probably one of the main difficulties in developing an effective international response to the emergence of increasingly autonomous military technology, either regulation or development ban. Due to political and practical issues, an international group of experts convened by the United Nations failed to create a definition of autonomous weapons systems that would be universally agreed upon or serve as a basis for a preventive ban on development. In this gap, various actors, from states to armed companies to scientists, have developed competing definitions for what they would consider LAWSs. ${ }^{3}$ The most common definition of LAWSs originated in a 2012 US Department of Defense (DOD) directive on autonomous weapon systems, which defines it as "a weapon system that, once activated, can select and shoot targets without further intervention by a human operator". ${ }^{4}$ The US Department of Defense definition has been used as the basis for multiple definitions of lethal autonomous weapons systems. However, according to some scholars, this definition is too broad. For example, Roff criticized the definition because the terms select and engage are open to interpretation. ${ }^{5}$ Horowitz emphasized the ability to choose a target that was not pre-selected by an operator. ${ }^{6}$ Crootof emphasized the weapon's ability to process information to make targeting decisions. ${ }^{7}$ We will end our attempt to define LAWS with couple more definitions to help us understand this issue. According to NGO Women's International League

3 Austin Wyatt, "So Just What Is a Killer Robot?", Wild Blue Yonder, June 08, 2020, pp. 68-81.

4 Department of Defense (DOD), Directive 3000.09, 21 November 2012, https://www.esd.whs.mil/. (accessed 11. August 2021)

${ }^{5}$ Heather Roff quoted in Ariel Conn to Future of Life Institute, November 30, 2016, https://futureoflife.org/2016/

11/30/problem-defining-autonomous-weapons/. (accessed 11. August 2021)

${ }^{6}$ Michael C. Horowitz, "The Ethics \& Morality of Robotic Warfare: Assessing the Debate over Autonomous Weapons," Daedalus, 145 (4/2016), pp. 25-36.

7 "A weapon system that, based on conclusions derived from gathered information and preprogrammed constraints, is capable of independently selecting and engaging targets" - Crootof, R. quoted in Michael C.

Horowitz, "Why Words Matter: The Real World Consequences of Defining Autonomous Weapons Systems,"

Temple International and Comparative Law Journal, 30 (2016), pp. 85-98. 
for Peace and Freedom's first definition, "Killer robots are fully autonomous weapon systems. These are weapons that operate without meaningful human control, meaning that only weapons can make decisions about where and how to use them; against what or against when it is used; and effects of use." scholars Austin Wyatt and Jai Galliott: "A fully autonomous Lethal Autonomous Weapon System (LAWS) is a weapon delivery platform that is able to independently analyze its environment and make an active decision whether to fire without human supervision or guidance." The third definition uses military ethicist Deonna Neal. She calls it a robot "which uses some form of artificial intelligence to guide its decisionmaking and that is capable of target discrimination and regulating its use of force independently of human' eyes on target' verification or authorization before it kills someone." 10 As can be seen from these definitions, the fundamental designation of LAWS is autonomy or independence in decision-making without human influence, when and against whom to act with deadly force. Sharkey warns us that when we speak the term "autonomy" in robots, "it must not be confused with the way the term is used in philosophy, politics, individual freedom, or in ordinary speech." 11 Therefore, Sharkey classified autonomous robots as: "(i) scripted, where the robots carry out a preplanned script; (ii) supervised, in which robots perform planning, sensing and monitoring functions with the help of human operators; and (iii) intelligent, which are described rather ambiguously as those in which 'attributes of human intelligence' are used in software for decision making, problem-solving,

\footnotetext{
${ }^{8}$ Ray Acheson, A WILPF Guide to Killer Robots, https://reachingcriticalwill.org/images/documents/Publications/wilpf-guideaws.pdf. (accessed 11. August 2021)

${ }^{9}$ Austin Wyatt and Jai Galliott, "Closing the Capability Gap: ASEAN Military Modernization during the Dawn of Autonomous Weapon Systems," Asian Security, 16 (1/2018), pp. 53-72.

${ }^{10}$ Deonna D. Neal, "In Defense of Humanity: Why Lethal Decision-Making Should Not Be Delegated to Machines," presentation at the meeting of the International Society for Military Ethics, San Diego, January 26, 2011.

11 Noel Sharkey, "Saying "no!" to lethal autonomous targeting," Journal of Military Ethics, 9(4/2010), p. 376.
} 
and perception and interpretation of information." ${ }^{12}$ However, according to Noorman and Johnson, all above definitions of autonomy ignores what we know about actual technological development: "Literature in the field of Science and Technology Studies (STS) shows that the trajectory of technological development is contingent, multidirectional, and dependent on complex negotiations among relevant social groups. Technologies that are adopted and used are not predetermined by nature or any other factor, and cannot be predicted in advance with certainty. In the course of development, the design of a new technology may morph and change in response to many factors including changes in funding, historical events such as wars, changes in the regulatory environment, accidents, market indicators, etc. The variety of conceptions of machine autonomy in the discourse of autonomous robots reflects the many ideas, ambitions and goals of the various social groups with a stake in the development of these technologies." 13 To understand the issue of autonomy as a critical determinant of LAWS, we must first understand what weapon autonomy is.

\section{UNDERSTANDING WEAPON AUTONOMY}

Since the invention of warfare, humankind has debated the morality of warfare and the weapons used in combat. So, likewise, every technological advance in the development of weapons comes questioning the ethics of their use in battle. Logan Nye, military journalist, points to these ethical issues in his article on the history of new weapons. Pope Urban II 1096 banned the crossbow because it was "deathly and hateful to God and unfit to be used by Christians". Those who were found in violation of this ban faced the punishment of excommunication and eternal damnation of the soul. Despite this, this precursor to the rifle was seen as too advantageous to keep on the shelf,

12 Noel Sharkey, "Cassandra or false prophet of doom: AI robots and war," IEEE Intelligent Systems, 23(4/2008), p. 16.

13 Merel Noorman and Deborah G. Johnson, "Negotiating autonomy and responsibility in military Robots," Ethics and Information Technology, 16 (1/2014), pp. 51, 56. 
and armies across Europe quickly added the crossbow to their formation. Even though the churches own a ban on the crossbow, in 1239, Pope Gregory IV used mounted crossbowmen against an alliance of Christian European Kingdoms known as the Lombard League. ${ }^{14}$

Nye points indicate that crossbows played a role in warfare until after the 15th century when advances in gunpowder slowly became obsolete. First, advanced cannons could break up their formations from further away than even the crossbowmen could fire. And muskets and rifles eventually filled the role that crossbowmen once had. But, of course, the church didn't love firearms either. It declared all black powder weapons to be daemonic, but armies quickly embraced them anyway. ${ }^{15}$ In the centuries that followed, military technology improved and has been moving toward automation for decades. The deployment of weapons with complete autonomy is foreseeable in the near future. Already the US Navy Phalanx system can autonomously search, detect and engage targets, but it has not yet been launched without direct human oversight and control. ${ }^{16}$ Britain's fire-and-forget Brimstone missiles can distinguish among tanks, cars and buses without human assistance and pursuit targets autonomously in pre-designated areas. According to an article published in New York Times, a swarm of Brimstones was deployed in Libya in 2011 against a group of tanks, which were destroyed in a coordinated way that would have been impossible for human operators. ${ }^{17}$ Israel's Harpy anti-radar missile system can detect and autonomously destroy enemy radars when they are

${ }^{14}$ Logan Nye, This common weapon was so 'pernicious' that Catholicism banned it, https://www.wearethemighty.com/mighty-history/catholic-churchbanned-crossbow-warfare/. (accessed 11. August 2021)

${ }^{15}$ Ibid.

${ }^{16}$ Gary E. Marchant; Braden Allenby; Ronald Arkin; Edward T. Barrett; Jason Borenstein; Lyn M. Gaudet; Orde Kittrie; Patrick Lin; George R. Lucas; Richard O'Meara and Jared Silberman, "International governance of autonomous weapons systems," Columbia Science and Technology Law Review, 12 (2011), 272, pp. 276-7.

17 John Markoff, "Fearing bombs that can pick whom to kill," New York Times, 12 November 2014. 
turned on. ${ }^{18}$ Likewise, Israel Jaguar semi-autonomous sentry robot has been designed to patrol and identify "suspicious elements" on the border with Gaza Strip. ${ }^{19}$ South Korea's SGR-A1 system similarly identifies and tracks intruders autonomously in the demilitarized border with North Korea and can be set to fire without human intervention. ${ }^{20}$ Above mentioned examples provides various battlefield advantages, including increased destruction capability, accuracy, range, and/or speed. This advancement of military technology has two consequences: soldiers are increasingly moving away from the battlefield, and the distance between soldiers and the battlefield increases. Advances in military technology have two consequences: soldiers are moving further away from the battlefield, and the distance between soldiers and the battlefield is increasing. The second is the increase in the autonomy of weapons, which accompanies the increase in soldiers' distance from the battlefield. The best example is the use of combat drones since drone pilots are usually stationed in military bases thousands of kilometers away from the battlefield and perform combat operations exclusively through computer screens. Because the drone pilot is thousands of miles away from battlefield, he is not in any physical danger. ${ }^{21}$ Drones represent a transitional phase between weapons entirely under human control, i.e. human in the loop systems and future LAWS that will operate fully

18 Kelsey Atherton, Loitering munitions preview the autonomous future of warfare, https://www.brookings.edu/techstream/loitering-munitions-previewthe-autonomous-future-of-warfare/ (accessed 11. August 2021)

${ }^{19}$ Joe Saballa, Israel Deploys Semi-Autonomous Machine Gun Robot to Gaza Border, https://www.thedefensepost.com/2021/07/01/israel-machine-gun-robotgaza-border/, (accessed 11. August 2021)

20 Alexander Velez-Green, The Foreign Policy Essay: The South Korean Sentry - A "Killer Robot" to Prevent War, https://www.lawfareblog.com/foreignpolicy-essay-south-korean-sentry-killer-robot-preventwar?_cf_chl_captcha_tk_=pmd_HHycTNRQbL0J43Q9QQvBHL4ICj55B2.r ZbreUGRFtHo-1630251724-0-gqNtZGzNAxCjcnBszQiR, (accessed 11. August 2021)

${ }^{21}$ Ivica Kelam, "U sjeni dronova - etički aspekti upotrebe dronova u ratu protiv terorizma," Filozofska istraživanja, vol. 144, (4/2016), pp. 686. 
autonomously, i.e., humans out of the loop. ${ }^{22}$ It is crucial to explain the terms human in, out, and on the loop in understanding LAWS. In military terminology, the loop is a term commonly used to explain how machine decision making operates. The loop is the decision-making framework by which someone (or something) gains information, decides what they will do, and then acts. Depending on the specific context in which it is being applied, the loop can also be called the kill chain or simply targeting. This framework can effectively be used across the spectrum of battlefield decision making - from rapid individual decision making in the heat of battle to strategic decision making for a large military formation. In military doctrine, it is often referred to as targeting. ${ }^{23}$ According to the official manual, US Military defines targeting as "the process of selecting and prioritizing targets and matching the appropriate response to them considering operational requirements and capabilities". ${ }^{24}$

In conclusion, let us mention Krishnan's interpretation of autonomy since he emphasizes three levels of machine autonomy. "Preprogrammed autonomous machines can perform functions autonomously but according to predetermined scripts - for instance, fire-and-forget missile systems in which precise targets are identified in advance but pursued autonomously by machines. Supervised machines follow more open-ended scripts - for instance, 'locate all tanks in this area and prompt for targeting'. Machines of this type are already operational; human operators oversee them but may be left to decide autonomously on targeting in the near future. Completely autonomous machines, on the other hand, would be able to learn and adapt their behaviour to changing

\footnotetext{
${ }^{22}$ On the ethics and legality of drone use, see more in: Ivica Kelam and Darija Rupčić, "(Ne)etičnost i (ne)legalnost upotrebe dronova u ratu protiv terorizma," Znakovi vremena, 19, 73, 2016, pp. 123-138.

${ }^{23}$ Patrick Eason Mackenzie, Lethal Autonomous Weapon Systems: Reconciling the Myth of Killer Robots and the Reality of the Modern Battlefield, https://dukespace.lib.duke.edu/dspace/bitstream/handle/10161/23212/Eason_du ke_0066N_16305.pdf?sequence=1\&isAllowed=y, (accessed 11. August 2021) ${ }_{24}$ The Joint Chiefs of Staff, Joint Publication 3-60, https://www.justsecurity.org/wp-content/uploads/2015/06/Joint_ChiefsJoint_Targeting_20130131.pdf, (accessed 11. August 2021)
} 
environments in pursuit of open-ended tasks. The ultimate goal of completely autonomous military robotics is to produce autonomous robot soldiers that could be deployed in battlefields and directed simply to neutralize enemy threats." 25

\section{LAWS OF ARMED CONFLICT AND LETHAL AUTONOMOUS WEAPON SYSTEM}

The first formal treaty prohibiting certain weapons in war was the St. Petersburg Declaration of 1868, banning the use of exploding bullets weighing less than four hundred grammes. According to Kellenberger, after the St. Petersburg Declaration, the international community has attempted two structures to regulate new technologies in warfare. The first consists of general principles and rules that apply to all means and methods of warfare due to the recognition that the imperative of humanity imposes limits to their choice and use. The second consists of international agreements that ban or limit specific weapons - such as chemical and biological weapons, incendiary weapons, anti-personnel mines, or cluster munitions. ${ }^{26}$ In the context of our paper, we will single out the International Humanitarian Law (IHL), which mainly consists of rules applied during armed conflict to protect persons who do not or no longer participate in hostilities. This set of rules regulates the conduct of hostilities. IHL sets limits on armed violence in order at least to reduce suffering and, according to the International Committee of the Red Cross, "is based on long-standing norms that are rooted in the tradition

${ }^{25}$ Pablo Kalmanovitz, "Judgment, liability and the risks of riskless warfare", Nehal C. Bhuta; Susane Beck; Robin Geiß; Hin-Yan, Liu and Claus Kreß (eds.) Autonomous weapons systems - Law, ethics, policy, Cambridge University Press, Cambridge 2016., p. 155.

26 Jakob Kellenberger, International Humanitarian Law and New Weapon Technologies, 34th Round Table on current issues of international humanitarian law, San Remo, 8-10 September 2011, https://internationalreview.icrc.org/sites/default/files/irrc-886-kellenberger-spoerri.pdf (accessed 11. August 2021). 
of all societies." ${ }^{27}$ The International Humanitarian Law rules have been developed and codified over in 20 century in international treaties, notably the 1949 Geneva Conventions and Geneva Conventions Additional Protocols of 1977. According to Droege, human rights protection does not cease in times of armed conflict, and that International Humanitarian Law and International Human Rights Legislation (IHRL) apply concurrently. Certain of these rights (including, among other things, the right to life) are, moreover, not subject to derogation, whatever the circumstances. ${ }^{28}$ The International Committee of the Red Cross points out the distinction between International Humanitarian Law and International Human Rights Legislation. International Humanitarian Law tends to provide more robust protection than International Human Rights Legislation against lethal force and the destruction of civilian property. ${ }^{29}$ The codification of International Humanitarian Law began with the Hague Conventions of 1899 and 1907, the first formal statement of war and war crimes laws in the body of secular international law. They define the qualifications of belligerents, such as acceptably proportionate methods of engaging the enemy and, tangentially, the prohibition of pillage within the seized territory as a result of war. ${ }^{30}$ The Geneva Conventions are four treaties and three additional protocols establishing international legal standards for humanitarian treatment in war. Signed in 1949 by 195 countries, the documents define the fundamental wartime rights of prisoners

27 International Committee of the Red Cross, The Basics of International Humanitarian Law - December 2017, ICRC, https://reliefweb.int/sites/reliefweb.int/files/resources/0850_002-IHL_web.pdf (accessed 11. August 2021).

${ }^{28}$ Cordula Droege, "The interplay between International Humanitarian Law and Human Rights Law in situations of armed conflict," Israel Law Review, 40 (2/2007), p. 311.

${ }^{29}$ International Committee of the Red Cross, The Basics of International Humanitarian Law - December 2017, ICRC, https://reliefweb.int/sites/reliefweb.int/files/resources/0850_002-IHL_web.pdf (accessed 11. August 2021).

${ }^{30}$ Jarna Petman, Autonomous Weapon Systems and International Humanitarian Law: 'Out of the Loop'?, Helsinki: The Eric Castren Institute of International Law and Human Rights, pp. 24-52. 
(Convention I), protections for the wounded (Convention II), as well as for civilians in a combat zone (Convention IV). The Geneva Conventions is relevant to the potential future deployment of LAWS as a set of rules maintaining human dignity and protecting the vulnerable and defenseless during the conflict. The point is that these restrictions directly comprise the legal framework to which LAWS must comply. In addition to these conventions, it is necessary to mention and include the Law of War. This legal term refers to the aspect of international law concerning acceptable justifications for entering the war (jus ad bellum $)^{31}$ and the limits to proper conduct once the war is being fought (jus in bello) $)^{32}$. In the following, we will explain the key terms from the conventions, proportionality and distinction, since their violation in warfare is considered a war crime. The advent of LAWS is fundamentally changing warfare, which is why it has recently emerged a movement the Campaign stop the killer robots ${ }^{33}$ that aims to ban the lethal autonomous weapon system precisely based on LAWS inability to maintain proportionality and distinction.

\section{Proportionality}

Additional Protocol I rule 14 to the Geneva Conventions states that an attack is disproportionate, thus illegal if it "among others, the following types of attacks are to be considered as indiscriminate: ...(b) an attack which may be expected to cause incidental loss of civilian life, injury to civilians, damage to civilian objects, or a combination thereof, which would be excessive in relation to the concrete and direct military

\footnotetext{
31 The definition of jus ad bellum is best explained in: Anders Henriksen, "Jus ad bellum and American Targeted Use of Force to Fight Terrorism Around the World," Journal of Conflict and Security Law, 19 (2/2014), pp. 211-250.

32 The definition of jus in bello is best provided in: Jasmine Moussa, Can "Jus ad Bellum" override "Jus in Bello"? Reaffirming the Separation of the two Bodies of Law', https://www.corteidh.or.cr/tablas/R22753.pdf (accessed 11. August 2021).

33 More about the Campaign to stop killer robots is available at: stopkillerrobots.org
} 
advantage anticipated." ${ }^{34}$ However, implementing the principle of proportionality in warfare is a significant problem in practice, as it is challenging to assess combat dynamics. Therefore, according to the official manual Force Operations and the Law: A Guide for Air, Space, and Cyber Forces of the Judge Advocate General of the Air Force, proportionality is "an inherently subjective determination that will be resolved on a case-by-case basis." ${ }^{35}$ Because proportionality is an inherently subjective determination, the use of LAWS would require the empirical calculation that must precede the authorization of an engagement (and under which, for instance, a LAWS must assess in advance civilian collateral damage) is intrinsically complicated. Moreover, the real-time analysis required to determine whether an attack is proportionate is profoundly contextual in practice. Current coding models cannot reliably capture it, and therefore the application of LAWS in warfare is hardly possible. According to Anderson and Waxman's view, the LAWS ability to assess proportionality is a technical issue (the design of software capable of measuring predicted civilian harm) and an ethical issue whereby weightings must be attached to relevant variables. ${ }^{36}$ Regarding to proportionality Christof Heyns wrote in his report to UN Assembly: "proportionality is widely understood to involve distinctively human judgement.. ${ }^{37}$ According to humanitarian law

${ }^{34}$ Protocol Additional to the Geneva Conventions of 12 August 1949, and relating to the Protection of Victims of International Armed Conflicts (Protocol 1), June 8, 1977, art. 51 (5)(b) (entered into force Dec. 7, 1978). available at: https://ihl-databases.icrc.org/customary-ihl/eng/docs/v1_rul_rule14 (accessed 11. August 2021).

${ }^{35}$ Tonya Hagmaier, Air Force Operations and the Law; a Guide for Air and Space Forces, USA: Air Force Advocate General's School Press, p. 21.

${ }^{36}$ Anderson, Kenneth; Matthew Waxman, Law and Ethics for Autonomous Weapon Systems: Why a ban won't work and How the Laws of War Can, STANFORD UnIVERSITY, THE HOOVER INSTITUTION JEAN PERKINS TASK ForCE ON NATIONAL SECURITY \& LAW ESSAY SERIES, 2013; AMERICAN UNIVERSITY, WCL ReSEARCH PAPER 2013-11; COLUMBia PUblic LaW RESEARCH PAPER 13351 (2013). p. 23.

${ }^{37}$ Christof Heyns, Report of the Special Rapporteur on extrajudicial, summary or arbitrary executions, UN Doc. A/HRC/23/47, https://documents-dds- 
principle of proportionality, the decision whether an attack "may be expected to cause incidental loss of civilian life, injury to civilians, damage to civilian objects, or a combination thereof, which would be excessive in relation to the concrete and direct military advantage anticipated" 38 , is according to Dinstein "complex, situational and valuebased." ${ }^{39}$ Proportionality requires an objective probability assessment of whether civilians or civilian objects could be harmed in the course of an attack, a strategic decision as to which military advantage is pursued, the ascription of relative values to both of these parameters and a balancing decision as to which value prevails over the other. ${ }^{40}$ In light of the total of the complexities involved in applying the proportionality principle in practice and the situational, value-based decisions that this assessment requires, we may indeed seriously doubt whether algorithms could ever master this task.

\section{Distinction}

The principle of distinction between civilians and combatants is now codified in Articles 48, 51(2) and 52(2) of Additional Protocol I, to the Geneva Conventions. According to Additional Protocol I, "the parties to the conflict must at all times distinguish between civilians and combatants. Attacks may only be directed against combatants. Attacks must not be directed against civilians. Acts or threats of violence, the primary purpose of which is to spread terror among the civilian population, are prohibited. Civilians are protected against attack unless and for such time as they take a direct part in hostilities. The parties to the conflict must at all times distinguish between civilian objects and

ny.un.org/doc/UNDOC/GEN/G13/127/76/PDF/G1312776.pdf?OpenElement, (accessed 11. August 2021).

38 Jean-Marie Henckaerts and Louise Doswald-Beck (eds.), Customary International Humanitarian Law, vol. I, Cambridge University Press and International Committee of the Red Cross, Cambridge 2005., rule 14 on p. 46.

39 Yoram Dinstein, The Conduct of Hostilities under the Law of International Armed Conflict, Cambridge University Press, Cambridge 2010., p. 140.

${ }^{40}$ Robin Geiß, "The principle of proportionality: force protection as a military advantage," Israel Law Review, 45 (2012), pp. 71-89. 
military objectives. Attacks may only be directed against military objectives. Attacks must not be directed against civilian objects. Civilian objects are protected against attack, unless and for such time as they are military objectives." ${ }^{\prime 4}$ Although the principle of distinction seems like an explicit obligation for all parties to the conflict, coherence is complicated. Especially given that there has been a shift from state-tostate warfare to conflicts characterized by urban battles among the civilian population, the distinction between legitimate targets and noncombatants was very difficult..$^{42}$ Combatants in unconventional armed conflict may not be wearing uniforms or insignia, making it testing for weapon routines to judge whether an individual (or, more challenging still, an individual within a body of persons) should be categorized as a relevant combatant. Krishnan points to the apparent problem of maintaining the principle of distinction in possible LAWS combat action: "distinguishing between a harmless civilian and an armed insurgent would be beyond anything machine perception could (sic) possibly do. In any case, it would be easy for terrorists or insurgents to trick these robots by concealing weapons or by exploiting their sensual and behavioural limitations." ${ }^{43}$ Today, it is difficult to define a civilian and a fighter in an age of unconventional conflicts between state and non-state actors. It will be difficult or impossible to create an algorithm and sensors that will always distinguish civilians from combatants. An additional problem for the use of LAWS is the situation when a combatant becomes hors de combat. According to Article 41 of Protocol I Geneva Conventions, a person hors de combat is a person who is no longer participating in hostilities by choice or circumstance. Under

${ }^{41}$ Protocol Additional to the Geneva Conventions of 12 August 1949, and relating to the Protection of Victims of International Armed Conflicts (Protocol 1), June 8, 1977, art. 51 (5)(b) (entered into force Dec. 7, 1978). available at: https://ihl-databases.icrc.org/customary-ihl/eng/docs/v1_cha_chapter1_rule1 (accessed 11. August 2021).

${ }^{42}$ Human Rights Watch, Losing Humanity, the Case against Killer Robots, https://www.hrw.org/sites/default/files/reports/arms1112_ForUpload.pdf (accessed 11. August 2021).

${ }^{43}$ Armin Krishnan, Killer Robots, Farnham: Ashgate Publishing, p. 99. 
customary international law, a person can be placed hors de combat in three situations arising in both international and non-international armed conflicts: an individual is considered to be hors de combat if he is in the power of an adverse party, has clearly expressed an intention to surrender or has been incapacitated by wounds and is therefore incapable of defending himself provided in all cases that a person abstains for hostile acts and refrains from escaping. ${ }^{44}$ The transition from combatant horse to combat presents an insurmountable challenge for LAWS since, in Sharkey's words: "humans understand one another in a way that machines cannot; cues can be very subtle and there are an infinite number of circumstances where lethal force is inappropriate." 45 Furthermore, Sharkey points out that the principle of distinction is an exceptionally subjective process stating: "The hard proportionality problem is making the decision about whether to apply lethal or kinetic force in a particular context in the first place. What is the balance between loss of civilian lives and expected military advantage? Will a particular kinetic strike benefit the military objectives or hinder them because it upsets the local population? The list of questions is endless. The decision about what is proportional to direct military advantage is a human qualitative and subjective decision. Such decisions must be made by responsible, accountable human commanders who can weigh the options based on experience and situational awareness. When a machine goes wrong it can go really wrong in a way that no human ever would." ${ }^{\prime 6}$ The difference between human and machine perception principle of distinction can be seen in the following example: "a frightened mother may run after her two children and yell at them to stop playing with toy guns near a soldier. A human soldier could identify with the mother's

44 ICRC, Practice Relating to Rule 47. Attacks against Persons Hors de Combat, https://ihl-databases.icrc.org/customary-ihl/eng/docs/v1_rul_rule47 (accessed 11. August 2021).

${ }^{45}$ Noel Sharkey, "Killing made easy: From Joysticks to Politics," Patrick Lin, Keith Abney, George A. Bekey (eds.), Robot ethics, the ethical and social implications of robotics, The MIT Press, Cambridge 2011., p. 118.

46 Noel Sharkey, "The evitability of autonomous robot warfare," International Review of the Red Cross, volume 94, issue 886 (2012), pp. 789-790. 
fear and the children's game and thus recognize their intentions as harmless, while a fully autonomous weapon might see only a person running toward it and two armed individuals. The former would hold fire, and the latter might launch an attack. Technological fixes could not give fully autonomous weapons the ability to relate to and understand humans that is needed to pick up on such cues." ${ }^{47}$ The inability to identify with humans and, consequently, the inability to express empathy (empathy is based on emotions that the machine does not possess) is the fundamental reason why LAWS are not and will never be able to maintain the principle of distinction fully.

\section{Responsibility}

Sparrow poses the following case. "Imagine that an airborne AWS [Autonomous Weapon System], directed by a sophisticated artificial intelligence, deliberately bombs a column of enemy five soldiers who have clearly indicated their desire to surrender. These soldiers have laid down their weapons and pose no immediate threat to friendly forces or non-combatants. Let us also stipulate that this bombing was not a mistake; there was no targeting error, no confusion in the machine's orders, etc. The AWS had reasons for what it did ... [but] they were not the sort to morally justify the action. Had a human being committed the act, they would immediately be charged with a war crime. Who should we try for a war crime in such a case?" 48 As noted above, Sharkey and other critics of LAWS have argued that they should be banned because they inherently preclude the fair attribution of responsibility. Since, by definition, LAWS autonomously decide which targets to engage, it would be unfair to hold commanders or anyone liable for a robot's decision. Fair criminal liability presupposes that commanders can foresee and intend the outcome of their actions.

47 Human Rights Watch, Losin humanity - The case against killer robots, https://www.hrw.org/sites/default/files/reports/arms1112_ForUpload.pdf (accessed 11. August 2021).

${ }^{48}$ Robert Sparrow, "Killer Robots," Journal of Applied Philosophy, 24 (1/2007), pp. 66-67. 
According to O'Connell, the autonomy of killer robots necessarily excludes both conditions. ${ }^{49}$ How do we hold human beings accountable for the actions of lethal autonomous weapon systems? And how are we going to get justice for the crime committed when the killer is essentially a computer? Our paper will primarily address legal responsibility, but moral responsibility is inextricably linked to legal responsibility. Sartor and Omicini identify clear accountability as the essential component in responsible weapon operation, linking functional failure with causality: "harm would not have resulted had the responsible component correctly exercised the function attributed to it. Indeed, any component and subcomponent of a socio-technical system may fail to exercise its function as expected. As a consequence, the system as a whole may fail, with harmful consequences, for which the malfunctioning component may be said to be responsible." ${ }^{50}$ Davey also points out that LAWS intent will be tough to determine given the human's increasing remoteness and exclusions and the consequent diffusion of agency that blurs any attribution of purpose..$^{51}$ Critics are rightly concerned about giving lethal decision-making powers to robots whose autonomous performance in complex environments would be uncertain. The so-called 'computer revolution of warfare' includes the extensive use of computerized sensors and complex data analysis and the future use of artificial intelligence for pattern recognition and other tasks. Elicit fears that machines will eventually be created that, as Krishnan pointed out, "can develop behaviours we did not anticipate and that we might not

49 Mary Ellen O'Connell, "Banning Autonomous Killing - The Legal and Ethical Requirement That Humans Make Near-Time Lethal Decisions," Matthew Evangelista and Henry Shue (eds.), The American Way of Bombing: Changing Ethical and Legal Norms, from Flying Fortresses to Drones, Cornell University Press, New York 2014., p. 233.

50 Giovanni Sartor and Andrea Omicini, "The autonomy of technological systems and responsibilities for their use," Nehal C. Bhuta; Susane Beck; Robin Geiß; Hin-Yan, Liu and Claus Kreß (eds.) Autonomous weapons systems - Law, ethics, policy, Cambridge University Press, Cambridge 2016., p. 62.

${ }^{51}$ Tucker Davey, Who is Responsible for Autonomous Weapons? Who is Responsible for Autonomous Weapons? - Future of Life Institute, (accessed 11. August 2021). 
even fully understand. The more complex and intelligent these machines become, the harder it will be to control their behaviour. This is not an immediate problem considering the relative simplicity of current robot software, but it could become a major problem in the future." ${ }^{52}$ In this context, Kalmanovitz highlights the dispersal of responsibilities among different agents: "the most troubling issue is not fairness but, rather, the fact that the complex organizational structure behind LAWS deployment can diffuse responsibility among many relevant agents a vanishing point. This diffusion can be counter-balanced only by a positive role-based regime of liabilities. The incentives to create and enforce such a regime do not currently exist. Whether and how they could be created is a most pressing and neglected practical question." ${ }^{53}$ Can a robot be a moral agent and therefore morally responsible? John Sullins believes an autonomous robot may be considered a moral agent if it satisfies three criteria: "significant autonomy - that is, the robot is not directly controlled by another agent and is effective at accomplishing its goals and tasks; intentional behaviour, where the complex interaction between the robot and its environment suggests deliberate and calculated behaviour; and responsibility, where the only way to make sense of the robot's behaviour is to assume it is responsible to some moral agent." ${ }^{44}$ However, Sparrow believes that such a fully developed autonomous system, which qualifies as a moral agent, does not currently exist or even if it will ever exist. ${ }^{55}$ Besides, when confronted with new technologies that generate risks, "we have also set up mechanisms to pressure those who make and use these technologies to operate them safely and take

\footnotetext{
52 Armin Krishnan, Killer Robots, Ashgate Publishing, Farnham 2009., p. 58.

${ }^{53}$ Pablo Kalmanovitz, "Judgment, liability and the risks of riskless warfare", Nehal C. Bhuta; Susane Beck; Robin Geiß; Hin-Yan, Liu and Claus Kreß (eds.) Autonomous weapons systems - Law, ethics, policy, Cambridge University Press, Cambridge 2016., p. 158.

${ }^{54}$ John P. Sullins, "When is a robot a moral agent?", International Review of Information Ethics, 6 (12/2006), pp. 28-29.

${ }^{55}$ Robert Sparrow, "Killer robots," Journal of Applied Philosophy, 24 (2007), pp. 65-66.
} 
responsibility when something goes wrong." ${ }^{56}$ Precisely because of all the above, critics rightly point out that the legally and ethically simplest solution is a global ban on the use of LAWS.

\section{ARE LAWS A THREAT TO HUMAN DIGNITY?}

A crucial point of our paper is how the introduction of LAWS could negatively change society, even dehumanize it, and how the law can prevent this from happening (or not). One aspect of this discussion is the question of human dignity. One could argue, for instance, that the confrontation with machines in specific contexts, without the possibility of escaping the situation, is a violation of human dignity. Or one could even regard the introduction of autonomous machines, because of the possible dehumanization of the society, to be a violation of the dignity of humanity as such. ${ }^{57}$ The notion of human dignity has become one of the essential integrative formulas in international politics. When introduced into Article 1 of the United Nations Universal Declaration of Human Rights in 1948, it has successfully functioned as an umbrella concept that connects seemingly insurmountable ideological views and provides a reasonable basis for consensus and compromise. ${ }^{58}$ According to the Human Rights Watch report: "all human rights derive from the dignity and worth inherent in the human person" 59 and asserts "that fully autonomous weapons could undermine the principle of dignity, which

\footnotetext{
56 Deborah Johnson, “Technology with no human responsibility?", Journal of Business Ethics, 127 (4/2014), p. 712.

57 Dieter Birnbacher, "Are autonomous weapons systems a threat to human dignity?" Nehal C. Bhuta; Susane Beck; Robin Geiß; Hin-Yan, Liu and Claus Kreß (eds.) Autonomous weapons systems - Law, ethics, policy, Cambridge University Press, Cambridge, 2016., pp. 105-121.

58 Universal Declaration of Human Rights, UN GA Res. 217 (III) A, 10 December 1948.

${ }^{59}$ Human Rights Watch and International Human Rights Clinic, Shaking the Foundations: The Human Rights Implications of Killer Robots, https://www.hrw.org/sites/default/files/reports/arms0514_ForUpload_0.pdf, (accessed 11. August 2021).
} 
implies that everyone has a worth deserving of respect". ${ }^{60}$ According to Scott, dignity in the Kantian tradition advances the idea of each person's infinite or incommensurable value. ${ }^{61}$ The issue of human dignity is also an insurmountable challenge for the military. U.S. Army Major General Robert Latiff wrote an article in Wall Street Journal in which he claims to have the decision whether you live or die - or be maimed - taken by machines is the ultimate indignity.

Perhaps the most philosophically compelling argument leveled against the use of LAWS is the human dignity argument claiming that "death by algorithm" is the ultimate indignity. In its more complex forms, the argument holds a fundamental human right not to be killed by a machine. From this perspective, human dignity, which is even more essential than the right to life, demands that a decision to take human life requires consideration of the circumstances by a human being. ${ }^{62}$ In the context of LAWS, a robot and not a human who decides to pull the trigger to take human life is considered a "dehumanization", suggesting that it is somehow against the dignity of humanity as a species. Christof Heyns, the United Nations special rapporteur on extrajudicial, summary or arbitrary executions in his 2013 report to the United Nations General Assembly, writes: "delegating this process [of deciding on targets] dehumanizes armed conflict even further and precludes a moment of deliberation in those cases where it may be feasible. Machines lack morality and mortality, and should as a result not have life and death powers over humans." ${ }^{\circ 3}$ On another occasion, Hynes claims: "death by algorithm means that people are treated simply as targets and not as complete and unique human beings, who may, by virtue of this status,

\footnotetext{
${ }^{60}$ Ibid.

${ }^{61}$ Rebecca J. Scott, "Dignité/dignidade: organising against threats to dignity in societies after Slavery," Christopher McCrudden (ed.), Understanding Human Dignity, British academy, London, p. 69.

${ }^{62}$ Christoph Bartneck; Christoph Lütge; Alan Wagner and Sean Welsh, An Introduction to Ethics in Robotics and AI, Springer Briefs in Ethics, Berlin 2021., p. 98.

${ }^{63}$ C. Heyns, Report of the Special Rapporteur on extrajudicial, summary or arbitrary Executions.
} 
deserve to meet a different fate." ${ }^{64}$ When we ask what constitutes the violation of human dignity, the answer depends on the catalogue of components of human dignity or fundamental human rights presupposed. Birnbacher makes the following list of fundamental human rights implied by human dignity: " 1 . the right not to be severely humiliated and made the object of public contempt; 2. the right to a minimum of freedom of action and decision; 3. the right to receive support in situations of severe need; 4. the right to a minimum of quality of life and relief of suffering; 5 . the right not to be treated merely as a means to other people's ends, i.e. without consent and with severe harm or risk of harm." ${ }^{65}$ According to Birnbacher, the threat to human dignity that LAWS constitute lies in their inherent risk of violating the fourth and fifth rights on the above mentioned list. The risk that their deployment involves is essentially that they pose threats to civilians that are incompatible with even a minimal quality of life and that they risk making civilians the mere means of aims that are in no way their own aims, with risks of serious harm to life and physical and mental integrity. LAWS have many features that are likely to cause severe dread, especially in civilians. ${ }^{66}$ Birnbacher point out LAWS are intrinsically incompatible with human dignity since LAWS cannot comprehend the value of human life; that, as machines, LAWS cannot take responsibility; and that, differently from human actors, a machine cannot act mercifully or compassionately. ${ }^{67}$ The similar argument stated in Human Rights Watch report on killer robots: "fully autonomous weapons could undermine the principle of dignity, which implies that everyone has a worth deserving of respect. As inanimate machines, fully autonomous weapons could truly comprehend neither the value of individual life nor

\footnotetext{
${ }^{64}$ Christof Heyns, "Autonomous weapons systems: living a dignified life and dying a dignified death," Nehal C. Bhuta; Susane Beck; Robin Geiß; Hin-Yan, Liu and Claus Kreß (eds.) Autonomous weapons systems - Law, ethics, policy, Cambridge University Press, Cambridge 2016., p. 11.

${ }^{65}$ D. Birnbacher, Are autonomous weapons systems a threat to human dignity?, p. 114.

${ }^{66}$ Ibid., p. 116.

${ }^{67}$ Ibid., p. 119.
} 
the significance of its loss. Allowing them to make determinations to take life away would thus conflict with the principle of dignity." ${ }^{96}$

We end this section with Birnbacher's insight: "we should beware of idealizations of human warfare. Historical experience provides plenty of examples of war practices that, in terms of the concept of human dignity as it is understood at present, have not only been clear cases of war crimes but, even worse, also violations of the dignity of their victims. The introduction of an autonomous weapon system does not mean the introduction of an altogether new quality of warfare. It introduces, however, new dangers and risks that should make us take precautions against potentially unethical uses of these weapons." ${ }^{\prime 69}$

\section{Conclusion}

In her essay Reflections on violence, Hannah Arendt, the great philosopher of the 20th century, seeks to distinguish between violence and power to capture the dimension that she considers to be specifically human. Violence is instrumental - a means to an end - and those means could well be enhanced by technological progress. However, violence in and of itself is in the service of something human: power, force and strength. Arendt speculates that: "no government exclusively based upon the means of violence has ever existed. Even the totalitarian ruler needs a power basis, the secret police and its net of informers. Only the development of robot soldiers, which would eliminate the human factor completely and, conceivably, permit one man with a pushbutton at his disposal to destroy whomever he pleases, could change this fundamental ascendancy of power over violence. Even the most despotic domination we know of, the rule of a master over slaves, who always outnumbered him, did not rest upon superior means of coercion as such but upon a superior organization of power, that is, upon the organized solidarity of

${ }^{68}$ Human Rights Watch and International Human Rights Clinic, Shaking the Foundations: The Human Rights Implications of Killer Robots.

${ }^{69} \mathrm{D}$. Birnbacher, Are autonomous weapons systems a threat to human dignity?, p. 121. 
the masters." ${ }^{70}$ Bhuta et al. point out that Arendt distinguishes between power and violence and reaches for the idea that the ends of violence domination, order, aggression, defence - are essentially purposive human actions that cannot in themselves be reduced to (or reproduced by) technological instruments. In Arendt example, "robot soldiers" mark a limit case or fantastic scenario that might conceivably make power secondary to violence. However, according to Arendt, such a vision is decidedly dystopic. Since obliterating the human factor from organized violence does not necessarily render it more dispassionate or more efficient but, rather, cauterizes its organic connection with the human faculty of action. The faculty of action is that which according to Arendt "enables human to get together with his peers, to act in concert, and to reach out for goals and enterprises which would never enter his mind, let alone the desires of his heart, had he not been given this gift - to embark upon something new." 71 Where human judgment and the faculty of action are displaced entirely from a field of activity, the activity itself is disarticulated from concrete, embodied, acting humans in a manner that makes the activity purely technical. ${ }^{72}$ In the spirit of Arendt thinking, we argue that with the development of LAWS, violence becomes a purely technical issue, wholly emptied of humanity. Therefore, it is pretty clear that the development and combat use of LAWS will continue in the near future. Because LAWS represents the absolute domination of technology over humanity, and in that sense, they represent the pinnacle of today's technological civilization. But, one must be aware that by constructing machines that make decisions for us, we are giving away a part of our

${ }^{70}$ Hannah Arendt, "Reflections on violence," New York Review of Books, 29 February 1969, http://www2.kobe-u.ac.jp/ alexroni/IPD\%202016\%20readings/ IPD\%202016_8/A\%20Special\%20Supplement_\%20Reflections\%20on\%20 Violence\%20by\%20Hannah\%20Arendt\%20_\%20The\%20New\%20Yor.pdf, (accessed 11. August 2021).

${ }^{71}$ Ibid.

72 Nehal Bhuta; Susanne Beck and Robin Geiß, "Present futures: concluding reflections and open questions on autonomous weapons systems," Nehal C. Bhuta; Susane Beck; Robin Geiß; Hin-Yan, Liu and Claus Kreß (eds.) Autonomous weapons systems - Law, ethics, policy, Cambridge University Press, Cambridge 2016., pp. 348-349. 
(social) identity or, more importantly, perhaps reconstructing our identity in a way that includes machines. Because we have earlier decided to use them for a specific part of our autonomy space - conduct and decisions that hitherto we had presupposed only humans could undertake directly. Thus, the very notion of what qualifies as a necessary or essential human judgment is socially, historically and technologically embedded, and autonomous machines challenge our self-understanding of what qualifies as human action. It has to be discussed further if and how autonomous machines can correspond to mistakes in a socially acceptable way. ${ }^{73} \mathrm{We}$ believe that they cannot, and that autonomous machines will never judge and bear the same legal and moral responsibility as humans. Indeed the only solution is a complete international ban on LAWS. And we conclude our paper with a final argument on LAWS illegality and immorality brilliantly explained by ethicist Peter Asaro: "I would submit that, when viewed from the perspective of engineering and design ethics, intentionally designing systems that lack responsible and accountable agents is in and of itself unethical, irresponsible, and immoral." ${ }^{\prime 4}$

\section{BIBLIOGRAPHY}

Acheson, Ray, A WILPF Guide to Killer Robots, https://reachingcriticalwill.org/images/documents/Publications/wilpf-guideaws.pdf. (accessed 11. August 2021).

Anderson, Kenneth; Waxman, Matthew, Law and Ethics for Autonomous Weapon Systems: Why a ban won't work and How the Laws of War Can, Stanford University, The Hoover Institution JeAn PERKIns TASK Force on NATIONAL SECURITy \& LAW ESSAY SERIES, 2013; AMERICAN UNIVERSITY, WCL RESEARCH PAPER 2013-11; COLUMBIA PUBLIC LAW RESEARCH PAPER 13-351 (2013), available at: https://scholarship.law.columbia.edu/faculty_scholarship/1803

\footnotetext{
${ }^{73}$ Ibid., p. 367.

74 Peter Asaro, "On banning autonomous weapon systems: human rights, automation, and the dehumanization of lethal decision-making," International Review of the Red Cross (Cambridge), volume 94, issue 886 (2012), p. 695.
} 
Arendt, Hannah, "Reflections on violence," New York Review of Books, 29 February 1969, http://www2.kobe-u.ac.jp/ alexroni/IPD\%202016\% 20readings/IPD\%202016_8/A\%20Special\%20Supplement_\%20 Reflections\%20on\%20Violence\%20by\%20Hannah\%20Arendt\%20_\% 20The\%20New\%20Yor.pdf, (accessed 11. August 2021).

Asaro, Peter, "On banning autonomous weapon systems: human rights, automation, and the dehumanization of lethal decisionmaking,"International Review of the Red Cross (Cambridge), volume 94, issue 886 (2012), pp. 687-709.

Atherton, Kelsey, Loitering munitions preview the autonomous future of warfare, https://www.brookings.edu/techstream/loitering-munitionspreview-the-autonomous-future-of-warfare/ (accessed 11. August 2021).

Bartneck, Christoph; Lütge, Christoph; Wagner, Alan and Welsh, Sean, An Introduction to Ethics in Robotics and AI, Springer Briefs in Ethics, Berlin 2021.

Bhuta, Nehal; Beck, Susanne and Geiß, Robin, "Present futures: concluding reflections and open questions on autonomous weapons systems," Nehal C. Bhuta; Susane Beck; Robin Geiß; Hin-Yan, Liu and Claus Kreß (eds.) Autonomous weapons systems - Law, ethics, policy, Cambridge University Press, Cambridge 2016.

Birnbacher, Dieter, "Are autonomous weapons systems a threat to human dignity?" Nehal C., Bhuta; Susane, Beck; Robin, Geiß; Hin-Yan, Liu and Claus, Kreß (eds.) Autonomous weapons systems - Law, ethics, policy, Cambridge University Press, Cambridge, 2016., pp. 105-121.

Davey, Tucker, Who is Responsible for Autonomous Weapons? Who is Responsible for Autonomous Weapons? - Future of Life Institute, (accessed 11. August 2021).

Droege, Cordula, "The interplay between International Humanitarian Law and Human Rights Law in situations of armed conflict," Israel Law Review, 40 (2/2007), pp. 310-355.

Geiß, Robin, “The principle of proportionality: force protection as a military advantage," Israel Law Review, 45 (2012), pp. 71-89.

Hagmaier, Tonya, Air Force Operations and the Law; a Guide for Air and Space Forces, USA: Air Force Advocate General's School Press.

Horowitz, Michael C., "The Ethics \& Morality of Robotic Warfare: Assessing the Debate over Autonomous Weapons," Daedalus, 145 (4/2016), pp. 25-36. 
Horowitz, Michael C., "Why Words Matter: The Real World Consequences of Defining Autonomous Weapons Systmes," Temple International and Comparative Law Journal, 30 (2016), pp. 85-98.

Henckaerts, Jean-Marie and Doswald-Beck, Louise (eds.), Customary International Humanitarian Law, vol. I, Cambridge University Press and International Committee of the Red Cross, Cambridge 2005.

Henriksen, Anders, "Jus ad bellum and American Targeted Use of Force to Fight Terrorism Around the World," Journal of Conflict and Security Law, 19 (2/2014), pp. 211-250.

Heyns, Christof, Report of the Special Rapporteur on extrajudicial, summary or arbitrary executions, UN Doc. A/HRC/23/47, https://documents-ddsny.un.org/doc/UNDOC/GEN/G13/127/76/PDF/G1312776.pdf?OpenEl ement (accessed 11. August 2021).

Heyns, Christof, "Autonomous weapons systems: living a dignified life and dying a dignified death," Nehal C. Bhuta; Susane Beck; Robin Geiß; Hin-Yan, Liu and Claus Kreß (eds.) Autonomous wapons systems Law, ethics, policy, Cambridge University Press, Cambridge 2016.

Johnson, Deborah, "Technology with no human responsibility?", Journal of Business Ethics, 127 (4/2014), https://www.law.upenn.edu/live/files/ 3774-johnson-d-technology-with-no-responsibility (accessed 11. August 2021).

Kalmanovitz, Pablo, "Judgment, liability and the risks of riskless warfare", Nehal C. Bhuta; Susane Beck; Robin, Geiß; Hin-Yan, Liu and Claus Kreß (eds.) Autonomous weapons systems - Law, ethics, policy, Cambridge University Press, Cambridge 2016.

Kelam, Ivica, "U sjeni dronova - etički aspekti upotrebe dronova u ratu protiv terorizma," Filozofska istraživanja, vol. 144, (4/2016), pp. 679-691.

Kelam, Ivica and Rupčić, Darija, "(Ne)etičnost i (ne)legalnost upotrebe dronova u ratu protiv terorizma," Znakovi vremena, 19, 73, 2016, pp. 123-138.

Kellenberger, Jakob, International Humanitarian Law and New Weapon Technologies, 34th Round Table on current issues of international humanitarian law, San Remo, 8-10 September 2011, https://international-review.icrc.org/sites/default/files/irrc-886kellenberger-spoerri.pdf (accessed 11. August 2021).

Krishnan, Armin, Killer Robots, Farnham: Ashgate Publishing.

Mackenzie, Patrick Eason, Lethal Autonomous Weapon Systems: Reconciling the Myth of Killer Robots and the Reality of the Modern Battlefield, 
https://dukespace.lib.duke.edu/dspace/bitstream/handle/10161/23212/Eason_du ke_0066N_16305.pdf?sequence=1\&isAllowed=y, $\quad$ (accessed 11 . August 2021)

Marchant, Gary E.; Allenby, Braden; Arkin, Ronald; Barrett, Edward T.; Borenstein, Jason; Gaudet, Lyn M.; Kittrie, Orde; Lin, Patrick; Lucas, George R.; O’Meara, Richard, and Silberman, Jared, "International governance of autonomous weapons systems,"Columbia Science and Technology Law Review, 12 (2011), 272, pp. 272-315.

Markoff, John, "Fearing bombs that can pick whom to kill," New York Times, 12 November 2014.

Merel, Noorman and Deborah G. Johnson, "Negotiating autonomy and responsibility in military robots, " Ethics and Information Technology, 16 (1/2014), pp. 51-62.

Moussa, Jasmine, Can "Jus ad Bellum" override "Jus in Bello"? Reaffirming the Separation of the two Bodies of Law', https://www.corteidh.or.cr/ tablas/R22753.pdf (accessed 11. August 2021).

O'Connell, Mary Ellen, "Banning Autonomous Killing -The Legal and Ethical Requirement That Humans Make Near-Time Lethal Decisions," Matthew Evangelista and Henry Shue (eds.), The American Way of Bombing: Changing Ethical and Legal Norms, from Flying Fortresses to Drones, Cornell University Press, New York 2014.

Petman, Jarna, Autonomous Weapon Systems and International Humanitarian Law: 'Out of the Loop'?, Helsinki: The Eric Castren Institute of International Law and Human Rights, pp. 24-52.

Neal, Deonna D., "In Defense of Humanity: Why Lethal Decision-Making Should Not Be Delegated to Machines," presentation at the meeting of the International Society for Military Ethics, San Diego, January 26, 2011.

Nye, Logan, This common weapon was so 'pernicious' that Catholicism banned it, https://www.wearethemighty.com/mighty-history/catholic-churchbanned-crossbow-warfare/. (accessed 11. August 2021).

Roff, Heather, quoted in Ariel Conn to Future of Life Institute, November 30, 2016, https://futureoflife.org/2016/

11/30/problem-defining-autonomous-weapons/. (accessed 11. August 2021).

Saballa, Joe, Israel Deploys Semi-Autonomous Machine Gun Robot to Gaza Border, https://www.thedefensepost.com/2021/07/01/israel-machinegun-robot-gaza-border/, (accessed 11. August 2021).

Sartor, Giovanni and Omicini, Andrea, "The autonomy of technological systems and responsibilities for their use," Nehal C. Bhuta; Susane Beck; Robin 
Geiß; Hin-Yan, Liu and Claus Kreß (eds.) Autonomous wapons systems - Law, ethics, policy, Cambridge University Press, Cambridge 2016.

Scott, Rebecca J., "Dignité/dignidade: organising against threats to dignity in societies after Slavery," Christopher McCrudden (ed.), Understanding Human Dignity, British academy, London.

Sharkey, Noel, "Cassandra or false prophet of doom: AI robots and war," IEEE Intelligent Systems, 23(4/2008), pp. 14-17.

Sharkey, Noel, "Saying "no!" to lethal autonomous targeting," Journal of Military Ethics, 9(4/2010), p. 369-383.

Sharkey, Noel, "Killing made easy: From Joysticks to Politics," Patrick Lin, Keith Abney, George A. Bekey (eds.), Robot ethics, the ethical and social implications of robotics, The MIT Press, Cambridge 2011.

Sharkey, Noel, "The evitability of autonomous robot warfare," International Review of the Red Cross, volume 94, issue 886 (2012), pp. 787-799.

Sparrow, Robert, "Killer Robots," Journal of Applied Philosophy, 24 (1/2007), pp. 62-77.

Sullins, John P., "When is a robot a moral agent?", International Review of Information Ethics, 6 (12/2006), pp. 24-30.

Universal Declaration of Human Rights, UN GA Res. 217 (III) A, 10 December 1948.

Velez-Green, Alexander, The Foreign Policy Essay: The South Korean SentryA "Killer Robot" to Prevent War, https://www.lawfareblog.com/ foreign-policy-essay-south-korean-sentry-killer-robot-preventwar?_cf_chl_captcha_tk_=pmd_HHycTNRQbL0J43Q9QQvBHL4I Cj55B2.rZbreUGRFtHo-1630251724-0-gqNtZGzNAxCjcnBszQiR, (accessed 11. August 2021)

Wyatt, Austin, “So Just What Is a Killer Robot?", Wild Blue Yonder, June 08, 2020, pp. 68-81.

Wyatt, Austin and Galliott, Jai, "Closing the Capability Gap: ASEAN Military Modernization during the Dawn of Autonomous Weapon Systems," Asian Security, 16 (1/2018), pp. 53-72.

Web-pages:

Department of Defense (DOD), Directive 3000.09, 21 November 2012, https://www.esd. whs.mil/. (accessed 11. August 2021).

Human Rights Watch, Losing Humanity, the Case against Killer Robots, https://www.hrw.org/sites/default/files/reports/arms1112_ForUpload.p df (accessed 11. August 2021). 
Human Rights Watch and International Human Rights Clinic, Shaking the Foundations: The Human Rights Implications of Killer Robots, https://www.hrw.org/sites/default/files/reports/arms0514_ForUpload_0. pdf,(accessed 11. August 2021).

ICRC, Practice Relating to Rule 47. Attacks against Persons Hors de Combat, https://ihl-databases.icrc.org/customary-ihl/eng/docs/v1_rul_rule47 (accessed 11. August 2021).

International Committee of the Red Cross, The Basics of International Humanitarian Law - December 2017, ICRC, https://reliefweb.int/sites/ reliefweb.int/files/resources/0850_002-IHL_web.pdf (accessed 11. August 2021).

The Joint Chiefs of Staff, Joint Publication 3-60, https://www.justsecurity.org/ wp-content/uploads/2015/06/Joint_Chiefs-

Joint_Targeting_20130131.pdf, (accessed 11. August 2021).

stopkillerrobots.org

https://ihl-databases.icrc.org/customary-ihl/eng/docs/v1_rul_rule14 (accessed 11. August 2021). 


\section{IVICA KELAM}

Sveučilište J. J. Strossmayera u Osijeku, Fakultet za odgojne i obrazovne znanosti/Kineziološki fakultet, Hrvatska

TOMISLAV NEDIĆ

Sveučilište J. J. Strossmayera u Osijeku, Akademija za umjetnost i kulturu, Hrvatska

\section{PRAVNI I ETIČKI ASPEKTI UPOTREBE SMRTONOSNIH AUTONOMNIH ORUŽANIH SUSTAVA U RATOVANJU}

Sažetak: Razvoj novih tehnologija, uvijek je pronalazio prvu primjenu u sferi ratovanja, od izuma luka i strijele, preko otkrića baruta do upotrebe bespilotnih letjelica u tvz. „ratu protiv terorizma“. Upravo je „uspješna“ upotreba bespilotnih letjelica u ciljanim ubojstvima „terorista“ dala dodatni poticaj za razvoj novih vrsta autonomnih oružja koji u potpunosti zamjenjuju vojnike od krvi i mesa na bojnom polju. Trenutno, veliku kontroverzu izazivaju potpuno autonomna oružja koja su u potpunosti autonomna u vršenju vojnih djelovanja, tj. mogu autonomno donositi odluku o primjeni smrtonosne sile protiv „neprijateljskih“ ljudskih bića. Ovakva vrsta autonomije izaziva brojne kontroverze, i to ne samo pravne već etičke. Dovodi u pitanje samu bit čovjeka, tj. da li je tzv. „ubojiti robot“ slijedeća evolucijska stepenica u razvoju ljudske vrste ili tehnološki povratak u barbarstvo. U radu ćemo analizirati neke od navedenih pravnih i etičkih dvojbi koje nas čekaju u vrlo skoroj budućnosti.

Ključne riječi: autonomija, pravo, etika, ljudsko dostojanstvo, ubojiti robot

Primljeno: 30.8 .2021 .

Prihvaćeno: 2.11.2021. 